\title{
Numerical and Experimental Approaches to Estimate Discharge Coefficients and Energy Loss Coefficients in Pressurized Grated Inlets
}

\author{
Jackson Tellez-Alvarez $^{1,2, * \mathbb{D}}$, Manuel Gómez ${ }^{1}{ }^{(\mathbb{D}}$, Beniamino Russo $^{3} \mathbb{D}$ and Marko Amezaga-Kutija ${ }^{4}$ \\ 1 FLUMEN Research Institute, Department of Civil and Environmental Engineering (DECA), Technical \\ University of Catalonia (UPC)—BarcelonaTECH, 08034 Barcelona, Spain; manuel.gomez@upc.edu \\ 2 Consorci Besòs Tordera/CCB Serveis Mediambientals, SAU, 08403 Granollers, Spain \\ 3 Group of Hydraulics and Environmental Engineering (GIHA), Technical College of La Almunia (EUPLA), \\ University of Zaragoza, La Almunia de Doña Godina, 050100 Zaragoza, Spain; brusso@unizar.es \\ 4 Cundall, 4th Floor Partnership House, Regent Farm Road, Newcastle upon Tyne NE3 3AF, UK; \\ m.amezagakutija@cundall.com \\ * Correspondence: jackson.david.tellez@upc.edu or jdtellez@besos-tordera.cat
}

\section{check for} updates

Citation: Tellez-Alvarez, J.; Gómez, M.; Russo, B.; Amezaga-Kutija, M. Numerical and Experimental Approaches to Estimate Discharge Coefficients and Energy Loss Coefficients in Pressurized Grated Inlets. Hydrology 2021, 8, 162. https://doi.org/10.3390/ hydrology 8040162

Academic Editors: Pierfranco Costabile and Luis Cea

Received: 2 August 2021

Accepted: 14 October 2021

Published: 26 October 2021

Publisher's Note: MDPI stays neutral with regard to jurisdictional claims in published maps and institutional affiliations.

Copyright: (c) 2021 by the authors. Licensee MDPI, Basel, Switzerland. This article is an open access article distributed under the terms and conditions of the Creative Commons Attribution (CC BY) license (https:/ / creativecommons.org/licenses/by/ $4.0 /)$.

\begin{abstract}
Numerical models concerning inlet systems are run to assess the hydraulic performance of existing or new systems and estimate the flow interchanges between the surface overland and sewer flows. In most programs, these interactions are modelled using the orifice equation, with estimated discharge coefficients around 0.6. In this paper, discharge values and energy loss coefficients for several pressurized grated inlets were obtained by experimental and numerical approaches and compared. To achieve these goals, a numerical model replicating several experimental tests carried out at the hydraulic laboratory of Universitat Politècnica de Catalunya (UPC) was produced using a CFD model (Flow 3D). This numerical model was found to be highly sensitive to the mesh size used; however, it was able to accurately simulate the experimental processes. The comparison considered different combinations of pressurized flow though the grate, between 10 to $50 \mathrm{l} / \mathrm{s}$, and different longitudinal gradients. The experimental discharge coefficient was found to increase with surcharging flowrate (ranging from 0.14 and 0.41 ), whereas the longitudinal gradient was found to have no effect. The discharge coefficients obtained in this study show that the standard 0.6 value commonly used by practitioners should be revised to a range between 0.14 to 0.41 , depending on circulating flow and inlet type. In addition, the loss coefficient values range from 0.25 to 3.41.
\end{abstract}

Keywords: grated inlet; discharge coefficient; energy loss coefficient; experimental tests; 3D numerical simulations

\section{Introduction}

Adapting modern cities to face future changes, including climate changes, requires modification of the main urban services design requirements, such as improved drainage systems to cope with extreme rainfall intensity producing flood events [1-5]. As rainfall events become more extreme, each city requires a personalized solution to cope with the problem of undersized sewer networks and poor surface drainage systems [6]. Integrated flood models give the opportunity for designers to simulate hypothetical situations to create customized drainage solutions. Flooding can be caused by a range of different sources, such as extreme pluvial events, irregular coastal tides and flooding due to failure of the urban drainage network. The latter of these is often modelled using integrated urban flood models [7], which are generally based on fluid motion as defined by the St. Venant equations [8]. Within this framework, 1D/2D coupled models are able to simulate at the same time 2D overland flow and 1D sewer flow, with the related links and flow interchanges through manholes and inlets [9-11]. In these models it is necessary to characterize the hydraulic performance of inlet systems in terms of hydraulic efficiency 
and to determine specific coefficients like discharge coefficients or energy losses coefficients in case of free or surcharged sewer flow conditions [12-16].

The aim of this paper is to estimate the discharge coefficient and energy loss of a surcharging drainage inlet, comparing the results obtained through experimental and modelling methods. By conducting both an experimental campaign and a computational fluid dynamics (CFD) model for the same tests, this work aims to analyse the effectiveness of a specific CFD modelling package in replicating surcharging inlets. A literature review was undertaken on the current state of the art of flood modelling and the challenges that have hindered further development. This includes the problems associated with modelling the interaction between the surface and subsurface networks, issues in replicating real life topography and the limitation of affordable computational power [17]. As part of this, a range of experimental papers that focused on energy losses and discharge coefficients around manholes and inlets were also reviewed. The papers focus on either normal drainage conditions or surcharged conditions for inlets and manholes; thus, this paper analyses and compares the energy loss coefficient and discharge coefficient parameters through experiments and numerical simulation.

The literature highlights the different software capable of integrating surface and subsurface models, such as the Storm Water Management Model (SWMM5.1) (by the US EPA), Integrate Catchment Modelling (ICM) Infoworks Package (By Innovyze), Mike Urban software (by DHI) and other tools developed by researchers, such as SIPSON [18] and CityCAT [19-21]. All of these models are based on the principle of solving the St. Venant equations to calculate the subsurface element of the model, but they differ in their surface water modelling techniques [8].

Further to the increases in computing power, there have also been vast improvements to Geographic Information Systems (GIS), providing more readily available terrain data [22,23]. "Dual drainage" models were introduced, instigating the initial attempt of simulating the interactions between the surface and subsurface models [24-26]. The term "dual drainage" was used in Djordjevic et al. [27] in reference to bi-directional flow between the overland and underground systems [28-30]. A challenge of these models is simulating the possible characteristics of flow between two sections, as the formulations on which these are based are still uncertain [31-33]. Bach et al. [23] produced a critical review of the history of urban drainage models in an attempt to improve the structure of knowledge on integrated flood models.

Hunter et al. [34] produced a benchmark for 2D hydraulic surface models, replicating storm events in urban areas through the assessment 6 models. Hunter et al. [34] concluded that if terrain data of a sufficiently high quality was available, then the model parameters become the most critical factor (vertical error $\sim 5 \mathrm{~cm}$ RMSE). Vojinovic et al. [35] used MIKE 11 and MIKE 21 (DHI 2019), a 1D/1D and 1D/2D model produced by the Danish Institute of Hydraulics (DHI), to assess the effect that model schematisation, geometry and range of parameters can have on coupled models and concluded that the success of the model is highly dependent on the accuracy of the Digital Terrain Model (DTM) utilised, stating that the effect of the frictional coefficient used is minimal in comparison.

Improvements in the field of geomatics have improved the quality of easily available elevation data. Historically, to gain the level of resolution to elevation required to produce surface runoff models, either photogrammetry or surveying techniques had to be undertaken [36]. Both of these methods are time intensive and costly in comparison to modern techniques. One mapping method that has led to improvements in Digital Elevation Models (DEM) is LIDAR (Laser Imaging, Detection And Ranging). By linking airborne and terrestrial LIDAR data, one can produce DEMs of a high quality (with a resolution of up to $5-10 \mathrm{~cm}$ ) at a much lower expense. This development made it possible to produce DEMs on a scale previously unattainable, which led to a growth in research relating to 2D surface runoff models [36]. As further advancements are made in the field of geomatics, the resolution and accuracy of DEMs continues to advance. As such, the limitations associated with poor topographical data become less significant, improving 
the flood model accuracy. On top of this, as the data collection process becomes more automated, the quantity, quality and density of data may increase dramatically [37]. Chen and Han [38] propose that with the large amount of new data being produced, the field of hydroinformatics can learn from big data technology, which has become increasingly popular in the past decade in the field of computer sciences and e-commerce.

A further challenge in producing an accurate bi-directional model is in calculating the flow transfer at the surface and subsurface connection points. Unreliable simulations can be caused by a poor understanding of the hydraulic behaviour of drainage structures [39-41].

The issue with utilising the orifice equation is the lack of knowledge on which discharge coefficient is applicable $[42,43]$. There are currently no guidelines on which discharge coefficient should be used, and therefore models often use a discharge coefficient of $0.6[43,44]$. Companies that design drainage grates, such as Neenah Foundry [45], focus on the resistance of the grates, as opposed to their hydraulic capabilities. Neenah Foundry proposes that a coefficient of 0.6 is to be used in calculating regular drainage conditions and does not state what should be used for surcharged conditions. Commercial drainage models such as Infoworks recommend using the standard small orifice equation with a coefficient of 0.6 for all type of conditions. This is, however, a coefficient that the user can alter.

Using an incorrect discharge coefficient leads to the model either over- or underestimating the extent of flooding events and flow hazard parameters (flow depth and velocities) [46-49]. Even though the difference in discharge between a discharge coefficient of 0.6 and one around 0.3 may be small for an individual grate inlet, models are used to design larger areas. In the case of a large urban city, there will be thousands of inlets, so the error would be much larger. In the case of an underestimation, the risk posed by the flood event would not be fully understood, which could lead to more damage being caused. An overestimation could lead to the scale of already costly drainage elements being increased without a genuine necessity.

Currently there is only small amount of data available from real life events, and this is usually only limited to discharges from limited discrete scenarios or surface flood extent [42]. A range of experimental studies have been conducted to monitor the flow into and out of drainage inlets. These include those by Bazin et al. [43], which assesses unspecified inlets, Gomez and Russo [16], Russo et al. [50], which assesses an inflow scenario with a grate present and Rubinato et al. [12], which looks at surcharged conditions when a manhole cover is not present. The papers reproduce scenarios that occur in the real world to try and reproduce data under a controlled environment.

Bazin et al. [43] aimed to evaluate the exchange between a flooded street and the subsurface, including scenarios where the underground system is in a surcharged position. Their work involved an experimental element from which the data was used to adapt and validate a flow exchange model, with the goal of producing a full numerical model of the interaction. It is not stipulated in the paper whether the street inlets have some style of grate above the entrance or whether they are just open holes leading to the gully pot. It should also be noted that most inlets are of a rectangular shape, as opposed to a square, and thus much larger. The dimension of the gully pot is also not considered, which implies it has not been designed to replicate a real drainage component. If there were a drainage grate in place, it is more than likely that this would affect the nature of the flow, as the scale of the gaps in the grate would be so small that it would disturb the flow more than a scaled-up version. On the other hand, if there were no grate on top of the model inlet, the model would also not replicate a real-life scenario as inlets are not open holes, they always have a grate. The range of the discharge coefficients given by this experiment is 0.39 to 0.46 .

Gomez and Russo [16] focused on the efficiency of drainage inlets in intercepting flow and moreover the change in hydraulic efficiency depending on the grate used. The goal outlined in this paper was to expand on the knowledge of the hydraulic behaviour of drainage structures, with the hope of improving the currently unreliable drainage models. 
Modification of the experimental platform located in the Laboratory of Hydraulics of the Technical University of Catalonia (UPC) allowed us to study the surcharging conditions of the grate inlet $[14,15,51]$.

\section{Materials and Methods}

The discharge coefficient of a grate under pressurized flow conditions was estimated; its values ranged between 0.1 and 0.41 in the study of Gomez et al. [15]. These are noticeably lower than the 0.6 used in most commercial models. The work of this study only looks at one grate, and therefore a similar experiment was undertaken for different grates to see how the discharge coefficients could differ.

The discharge coefficient of a surcharged inlet was calculated using the orifice equation. This equation was selected because of it is one of the most common methods to estimate flow transfer in commercial integrated flood models. These values were calculated by rearranging the orifice equation, as follows:

$$
C_{d}=\frac{Q}{A_{g} \sqrt{2 g \Delta h}}
$$

where $C_{d}$ is the discharge coefficient, $Q$ is the discharge passing through the grate $\left(\mathrm{m}^{3} / \mathrm{s}\right)$, $A_{g}$ is the area of gaps in the grate $\left(\mathrm{m}^{2}\right), g$ is the gravitational acceleration $\left(9.81 \mathrm{~m} / \mathrm{s}^{2}\right)$, and $\Delta h$ is the average water depth above the grate (taking the grate as a datum) (m).

In order to estimate the $C_{d}$ for the grate, Equation (1) was considered, and for each surcharge grate, water levels were measured over the grate inlet at 20 points in order to achieve the average flow depth.

The height component of the formula, for both the experimental data and model data, was calculated by taking an average of 20 points located above the grate.

Fluids are susceptible to energy loss when in motion. The loss in energy in the fluid is controlled by the geometry and roughness of the section, the type of fluid and the motion of the fluid. The energy losses can be split into two different categories: frictional losses and minor losses. Frictional losses are usually attributed to flow over a channel or a pipe and are dependent on whether the fluid flow is laminar or turbulent, the viscosity of the fluid and the material and size of the pipe/channel. Minor losses occur when there is a change in the geometry of the section, a common example being a contraction or expansion of a pipe. By placing a grate over a drainage inlet, there is a change in the minor losses. This has been calculated by comparing the water depth above the inlet without a grate present and using Equation (2):

$$
k=\Delta h \frac{2 g}{v^{2}}
$$

where $k$ is the energy loss coefficient, $\Delta h$ is the change in height caused by the introduction of a grate $(\mathrm{m}), g$ is gravitational acceleration $\left(9.81 \mathrm{~m} / \mathrm{s}^{2}\right)$, and $v$ is the velocity of discharge through the grate, calculated as Flowrate divided by area of gaps $\left(\mathrm{m} / \mathrm{s}^{2}\right)$.

\subsection{Experimental Set-Up}

The experimental campaign of this paper was undertaken using a grate inlet located in the Hydraulic Lab of the Technical University of Catalonia (UPC) ( $t 1$ ) on a dynamic platform that simulates a road. In the past, the facility has been utilised to simulate a range of experiments related to inlet efficiency to capture flows $[16,50]$, but has since been altered to allow for simulations of surcharge conditions. The platform is a 1:1 scale of a road, with a width of $3 \mathrm{~m}$ and a total length of $5.5 \mathrm{~m}$, where a single inlet can be tested (Figure 1). The two grates used for the experimental section of this study are grates 1 and 2 in Figure 2. Both grates, along with grate 3, were used for the numerical simulation in Flow 3D. Grates were examined previously in [14,15,52], and grate 2 was tested during the period of internship of Amezaga-Kutija [53]. 


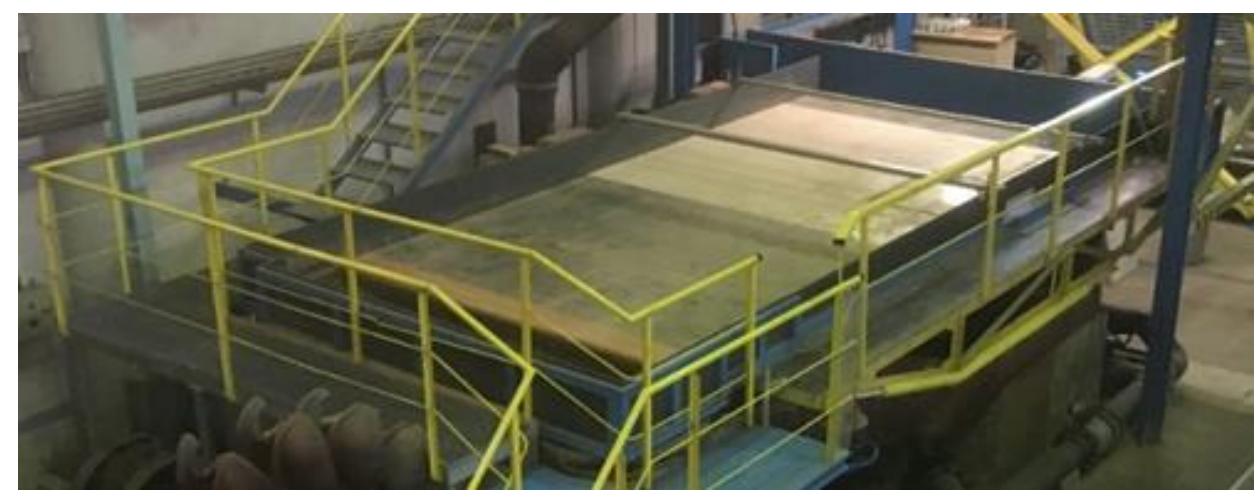

Figure 1. The hydraulic platform used in the experiment.

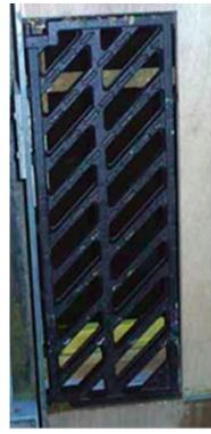

Grate Type 1

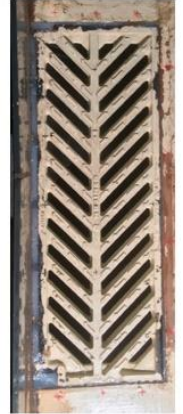

Grate Type 2

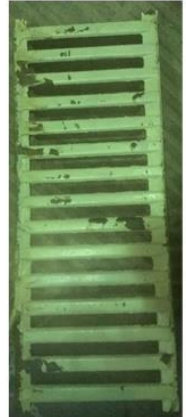

Grate Type 3

Figure 2. The grates inlet tested and simulated.

The platform has the potential to be tilted in both the longitudinal direction $(0-10 \%)$ as well as in the transverse direction (0-4\%). The water supply to the platform was designed to support flowrates between $1 \mathrm{l} / \mathrm{s}$ and $200 \mathrm{l} / \mathrm{s}$ [51]. For the surcharged case, flowrates of $50 \mathrm{l} / \mathrm{s}$ or less were selected because with higher flowrates the height of the surcharging flow goes over the barrier surrounding the platform (approximately $20 \mathrm{~cm}$ ). The desired flowrate is achieved by giving the water gravitational potential energy before being supplied to the model. A pump ( $50-60 \mathrm{~Hz}$ and $90-108 \mathrm{~kW}$ ) takes the flow from the hydraulics lab (in the basement) to a tank on the roof of the building at a height of approximately $15 \mathrm{~m}$. The supply to the model is controlled from the roof via an electronic valve and is measured using an electromagnetic flow meter, which measures to an accuracy of $11 / \mathrm{s}$ (Type MQI 99, ELA company, Brno, Czech Republic). The flow enters the model via a flexible pipe (diameter $200 \mathrm{~mm}$ ) going into the centre of the base of the glass inlet chamber underneath the grate (dimensions $90 \mathrm{~mm} \times 30 \mathrm{~mm} \times 50 \mathrm{~mm}$ ). As well as resembling real life inlets, another benefit of adding the flow at the base of the chamber is that it dissipates kinetic energy and allows the flow to be equal across the grate.

\subsection{Data Collection}

The test was conducted with 5 flowrates $(101 / \mathrm{s}, 201 / \mathrm{s}, 30 \mathrm{l} / \mathrm{s}, 40 \mathrm{l} / \mathrm{s}$ and $50 \mathrm{l} / \mathrm{s})$ for 6 different longitudinal gradients $(0 \%, 2 \%, 4 \%, 6 \%, 8 \%, 10 \%)$ with a $2 \%$ transverse slope, giving a total of 30 experimental configurations.

For each configuration, the water depth was measured at 67 locations, of which 20 were located on the top of the grate. The average of these 20 measurements was taken to be the average water depth above the grate and was used in calculating the discharge coefficient (Figure 3). The water depth was measured above the grate manually using a depth gauge with an accuracy of $1 \mathrm{~mm}$. The range of values of average water depth was $0.030 \mathrm{~m}(10 \mathrm{l} / \mathrm{s})$ to $0.105 \mathrm{~m}(50 \mathrm{l} / \mathrm{s})$. Water depths with stable flowrate have been measured with a gauge with an accuracy of $1 \mathrm{~mm}$, but the error of measure can increase with increased flow rate because of the flow fluctuations. 


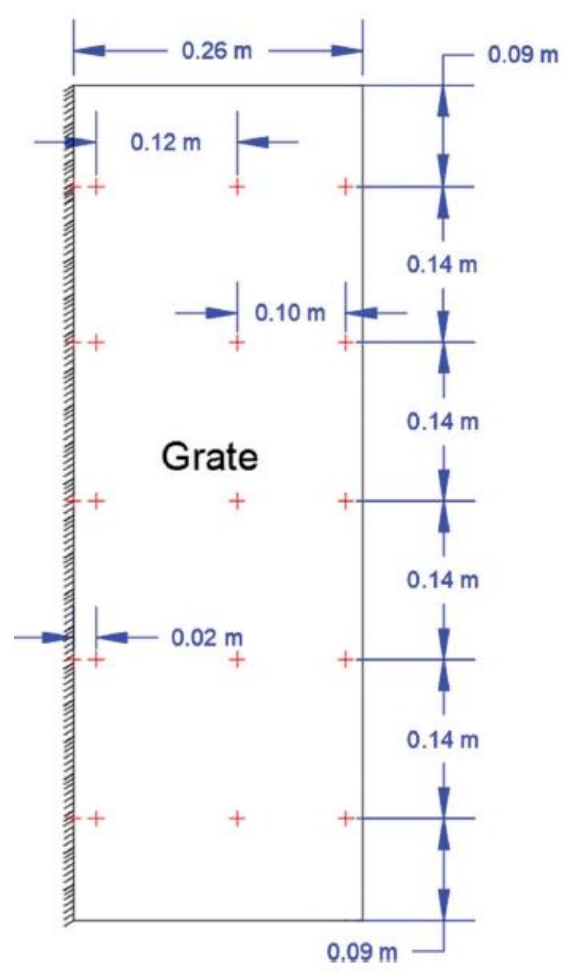

Figure 3. Depth location of water level measurement over the grate [15].

\subsection{Numerical Simulation}

A numerical model was applied to simulate the same scenarios as outlined in the experimental campaign. The CFD model utilised is the commercially available Flow 3D developed by Flow Science Inc., Santa Fe, NM, USA [54]. The modelling process can be separated in to 3 sections: pre-processing, processing and post-processing. The preprocessing involves designing the model, which includes stating geometry and any inputs. The processing stage is when the simulation is made by the calculation of the equations stated below. Post-processing is the extraction and presentation of data from the completed model. This was completed using an attachment to Flow 3D called Flow-sight.

\subsubsection{Numerical Model}

Flow 3D has applications in a variety of fields, as it is capable of simulating a large range of different fluids [55-59]. For three-dimensional incompressible flows, the governing equations behind Flow 3D are summarized in Equations (3)-(6):

$$
V_{F} \frac{\partial \rho}{\partial t}+\frac{\partial}{\partial x}\left(u A_{x}\right)+\frac{\partial}{\partial y}\left(v A_{y}\right)+\frac{\partial}{\partial z}\left(w A_{z}\right)=\frac{R_{S O R}}{\rho}
$$

where $V_{F}$ is the fractional volume open to flow, $\rho$ is the density, $u, v, w$ are the velocity components, $A_{x}, A_{y}, A_{z}$ are the fractional areas in the $x, y$ and $z$ directions, respectively, and the source term of density is $\mathrm{R}_{\mathrm{SOR}}$.

$$
\begin{gathered}
\frac{\partial u}{\partial t}+\frac{1}{V_{F}}\left\{u A_{x} \frac{\partial u}{\partial x}+v A_{y} \frac{\partial u}{\partial y}+w \frac{\partial u}{\partial z}\right\}=-\frac{1 \partial p}{\rho \partial x}+G_{x}+f_{x} \\
\frac{\partial v}{\partial t}+\frac{1}{V_{F}}\left\{u A_{x} \frac{\partial v}{\partial x}+v A_{y} \frac{\partial v}{\partial y}+w A_{z} \frac{\partial v}{\partial z}\right\}=-\frac{1 \partial p}{\rho \partial y}+G_{y}+f_{y} \\
\frac{\partial w}{\partial t}+\frac{1}{V_{F}}\left\{u A_{x} \frac{\partial w}{\partial x}+v A_{y} \frac{\partial w}{\partial y}+w A_{z} \frac{\partial w}{\partial z}\right\}=-\frac{1 \partial p}{\rho \partial x}+G_{z}+f_{z}
\end{gathered}
$$


where $G_{x}, G_{y}, G_{z}$ are body accelerations in the coordinate directions $(x, y, z)$ and $\left(f_{x}, f_{y}, f_{z}\right)$ are the viscos accelerations in the coordinate direction $(x, y, z)$, respectively.

To solve all these equations described, it was necessary to define the gravity terms in the " $z$ " axis with the value of $9.81 \mathrm{~m} / \mathrm{s}^{2}$, using the first order method. The parameter of gravity in the " $x$ " and " $y$ " directions changed according to the inclination of the platform for the different combinations of geometry (longitudinal and transversal slopes) studied.

The turbulence model used is RNG, as it gives better performance when compared with other models [57]; the equations used are (7) and (8):

$$
\begin{gathered}
\frac{\partial}{\partial t}(\rho \mathrm{k})+\frac{\partial}{\partial x_{i}}\left(\rho k u_{i}\right)=\frac{\partial}{\partial x_{j}}\left[\left(\mu+\frac{\mu_{t}}{\sigma_{k}}\right) \frac{\partial k}{\partial x_{j}}\right]+P_{k}-\rho_{\varepsilon} \\
\frac{\partial}{\partial t}(\rho \varepsilon)+\frac{\partial}{\partial x_{i}}\left(\rho \varepsilon u_{i}\right) \frac{\partial}{\partial x_{j}}\left[\left(\mu+\frac{\mu_{t}}{\sigma_{\varepsilon}}\right) \frac{\partial \varepsilon}{\partial x_{j}}\right]+C_{1 \varepsilon} \frac{\varepsilon}{k} P_{k}-C_{2 \varepsilon} \rho \frac{\varepsilon^{2}}{k}
\end{gathered}
$$

where $\varepsilon$ is the energy dissipation rate per unit mass, $k$ is the turbulence energy per unit mass (TKE), $t$ is the time, $x_{i}$ is the coordinate in the $i$-axis, $u$ is the dynamic viscosity, $\mathrm{u}_{\mathrm{t}}$ is the turbulent dynamic viscosity, and $P_{k}$ is the production of TKE. The term of turbulence viscosity was estimated using Equation (9):

$$
\mu_{t}=\rho C_{\mu} \frac{k^{2}}{\varepsilon}
$$

The values of the terms $C_{1 \varepsilon} ; C_{2 \varepsilon} ; \sigma_{\varepsilon}$ and $C_{\mu}$ were defined according to [57-59].

\subsubsection{Pre-Processing}

The initial stage of pre-processing defines the model geometry. As the model is made to match the experimental set-up, the model should be a copy of the experimental set-up. The components that are used in the final model were drawn using an Autodesk product called Civil 3D. As Flow 3D allows multiple geometric files to be loaded at the same time, each of the components were drawn separately. This allows the simulation to be repeated with different grates and only having to redraw the grate section. The files were exported from Civil 3D in the "Stereo Lithography" (.stl) format, to be imported into Flow 3D. Once the geometry was imported, a mesh size had to be calculated. The mesh size is the length of each side of each calculated hexahedron (cube). The smaller the size of the mesh, the more accurate the model; however, the smaller the mesh, the longer the model takes to compute. To transform the input geometry into a format that the processor can read, the pre-processor uses a technique named FAVOUR (Fractional Area/Volume Obstacle Representation). FAVOUR takes each hexahedron and calculates the proportions of its solid area, and reconstructs the solid. If the mesh selected isn't too large, this provides an effective mechanism to reduce the complexity of an object. Each cell being either solid or not helps reduce the computing time of the model.

The mesh size has an effect on the quality of the grate model. It is clear from Figure 4 that the $2 \mathrm{~cm}$ mesh and $3 \mathrm{~cm}$ mesh sizes are too big, as the grate is significantly distorted, whereas the other mesh sizes keep the correct shape. For this reason, one would expect there to be a significant difference between the results given by the $2 \mathrm{~cm}$ and $3 \mathrm{~cm}$ mesh as compared to the other ones. Another key aspect that must be considered is the time taken for running a simulation. To test this, a simulation was run for 1 scenario for each mesh size (30 l/s, $4 \%$ longitudinal gradient), and the computing time was compared. The $0.5 \mathrm{~cm}$ size took $920 \mathrm{~min}$, which means that if all the scenarios had been completed with this cell size, it would have taken approximately 19 days for the model to run. All model durations are outlined in Table 1. Figure 5 shows there is an exponential relationship between the cell size and the time taken to run the model A mesh size of $1 \mathrm{~cm}$ was selected, as it gave comparably accurate water levels, and therefore discharge coefficients, to the $0.5 \mathrm{~cm}$ mesh 
without an excessive time delay. Each simulation took approximately $25 \mathrm{~min}$ and contained 324,064 cells.
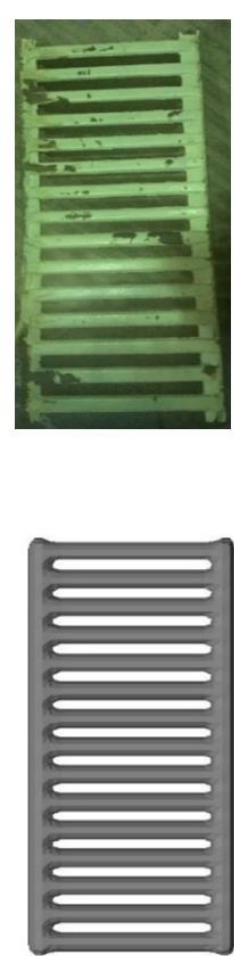

$1.25 \mathrm{~cm}$

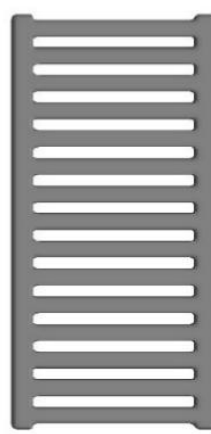

$0.5 \mathrm{~cm}$

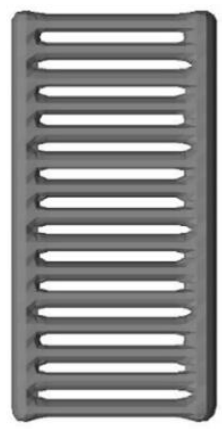

$1.5 \mathrm{~cm}$

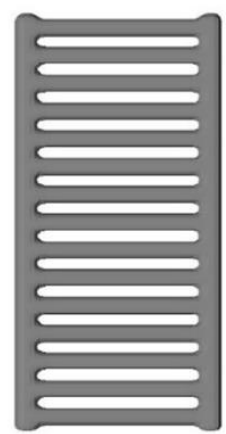

$0.75 \mathrm{~cm}$

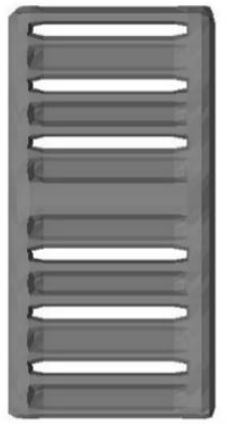

$2 \mathrm{~cm}$

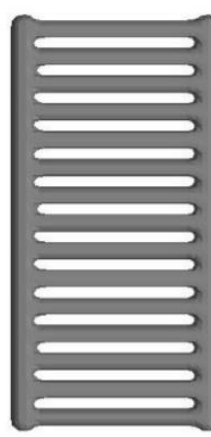

$1 \mathrm{~cm}$

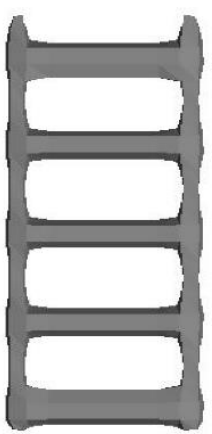

$3 \mathrm{~cm}$

Figure 4. Difference in grate geometry as dependent on cell size.

Table 1. Comparison of duration of simulation for different sized cells.

\begin{tabular}{ccc}
\hline Cell Size (cm) & Time (mins) & Total Number of Cells (Unit) \\
\hline 0.5 & 920 & $25,292,512$ \\
0.75 & 139 & 772,701 \\
1 & 25 & 324,064 \\
1.25 & 11 & 164,240 \\
1.5 & 5 & 94,875 \\
2 & 2 & 40,508 \\
3 & 0.8 & 12,285 \\
\hline
\end{tabular}

Another aspect of the simulation that needs to be defined in Flow 3D is the turbulence model for which to run the system. Three turbulence models are available in Flow 3D: RNG (renormalized group), $k-\omega$ and $k-\varepsilon$. Simulations were performed using the three turbulence models. Water depth was taken at the same point as the previous section of this model set. The RNG turbulence model was ultimately selected, as it was both the most stable and the quickest model, taking $25 \mathrm{~min}$, where $\mathrm{k}-\omega$ and $\mathrm{k}-\varepsilon$ took 34 and $33 \mathrm{~min}$. respectively. This is in line with other similar studies conducted by Gomez et al. [55] using Flow 3D.

The model was composed of two nested blocks: block mesh 1, with dimensions of $1.8 \mathrm{~m} \times 1 \mathrm{~m} \times 0.7 \mathrm{~m}$ and a cell size of $2 \mathrm{~cm}$, and block mesh 2, with dimensions of $0.94 \times 0.6 \times 1.37 \mathrm{~m}$ and a cell size of $1 \mathrm{~cm}$. The domain was composed of 1,039,988 cells that represent the grate inlet under pressure in the real scale model, as shown in Figure 6 [59]. 


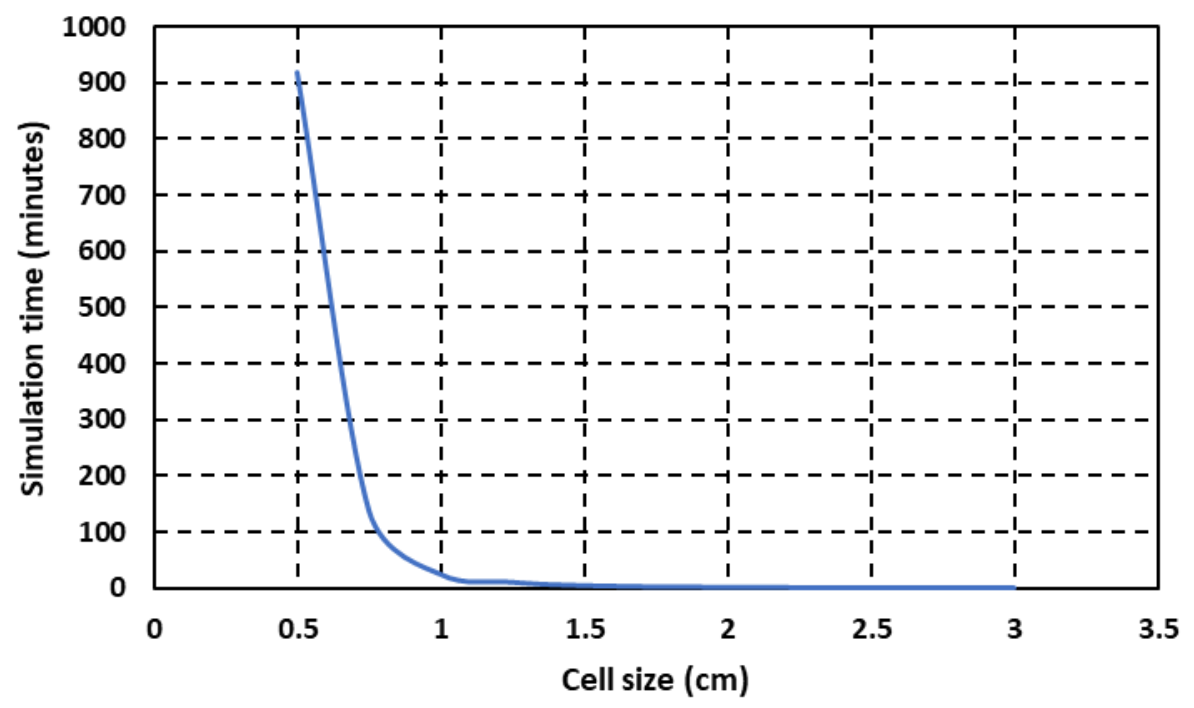

Figure 5. Graph of variation of simulation time depending on cell size.

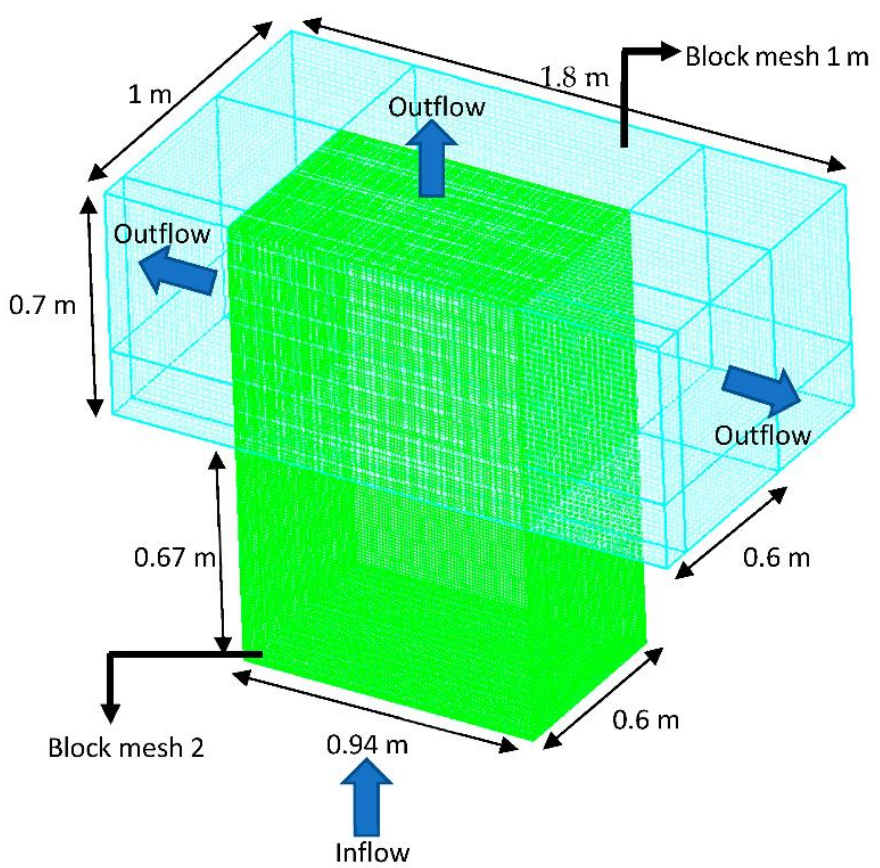

Figure 6. Mesh domain of the model [57].

The boundary conditions (BC) established for this model were the volume flowrate, specific pressure, the barrier wall and the outflow. For each case, the inflow was established at the specific boundary at the base of block mesh $2\left(Z_{\min }\right)$ as a flowrate between $101 / \mathrm{s}$ and $501 / \mathrm{s}$.

The motion of fluid was evaluated with the numerical approach of Reynolds Averaged Navier Stokes equation (RANS) to solve the momentum and continuity equations, and the momentum advection was evaluated using the first order accuracy. In addition, Flow 3D uses the VOF method (Volume Of Fluid) for multiphase flows, which considers the integration between water and air in the simulation. It assigns to the cell a number between 1 and 0 , where 1 is a full cell of water and 0 is a cell of only air. This allows for a smoother edge in the simulation, without using an absurdly small cell size. 
Flow 3D completes Equations (3)-(9) using a finite volume method. The hexahedron cells defined by the FAVOUR method are used as the centre points for the calculations, giving each cell a single temperature, pressure and velocity.

\subsubsection{Post-Processing}

The post processing is completed using a Flow 3D add-on named Flow Sight, which is used to visualise the results from Flow 3D. The tool which most used from Flow Sight was the recording of the average depth of 20 points, as shown in the Figure 3, above the grate, used to calculate the discharge coefficient and energy loss. The visual element was also used to try to compare the simulation to images taken from the experiments to judge the effectiveness of matching the flow. Figure 7 shows comparisons between the Flow 3D simulations and the tests from a visual perspective. The quality of comparison was limited by the quality of the camera; however, a clear progression can be visualised throughout the discharges.

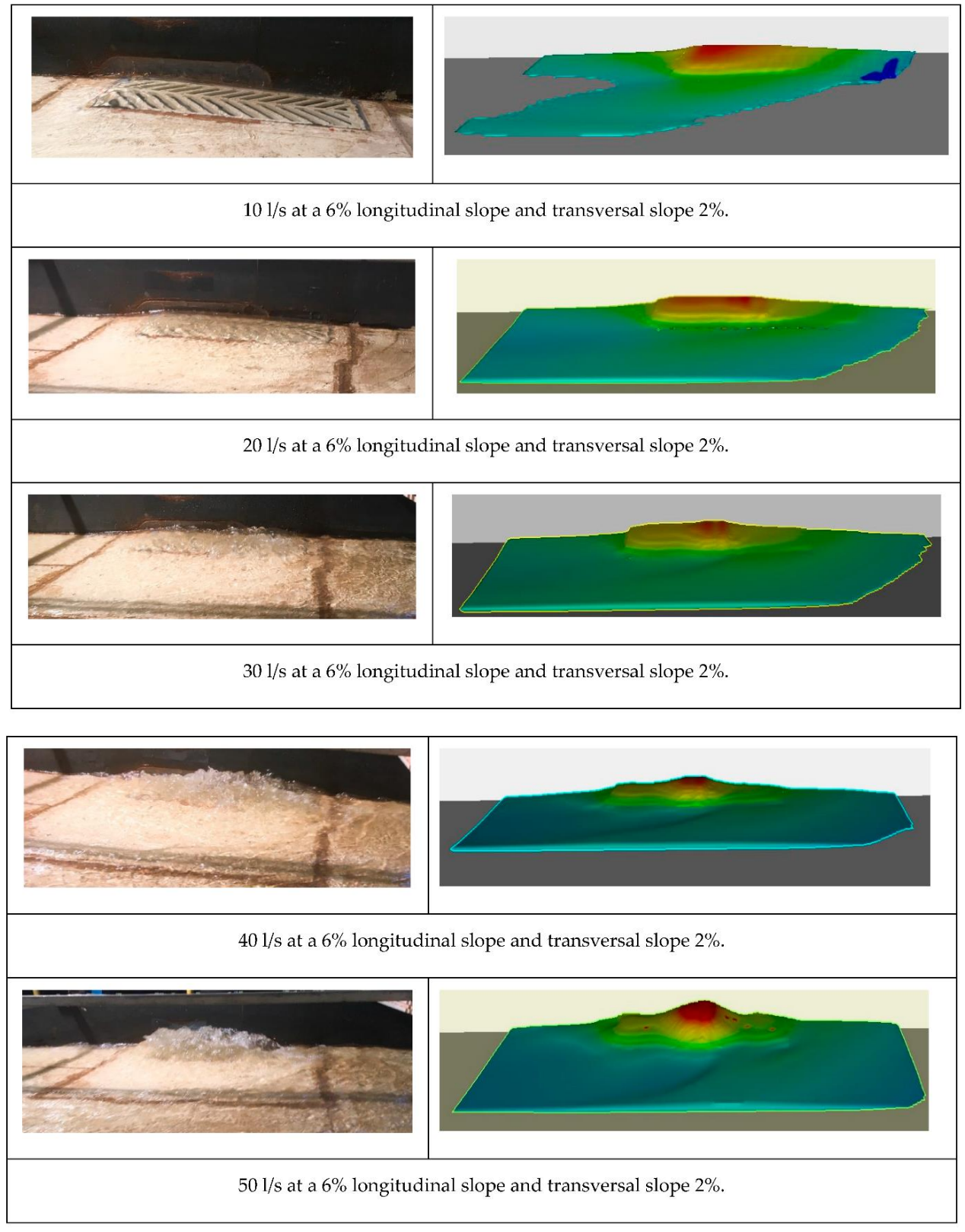

Figure 7. Visual comparisons of the Flow 3D simulations and the tests. 


\section{Results}

The comparison of the results of the discharge coefficients and energy loss coefficients are described in this section through an analysis of the values, where the transversal slope is fixed to $2 \%$ and the longitudinal slope is between 2 and $10 \%(2 \%, 4 \%, 6 \%, 8 \%$ and $10 \%)$. In both the experimental and numerical tests, the longitudinal gradient had no effect on the discharge coefficient $[14,15]$. Therefore, a mean value for each flowrate was taken. In all cases, the flowrates studied were 10,20,30, 40 and $50 \mathrm{l} / \mathrm{s}$, considering an average value of the water level over the grate and measuring the water level at 20 points.

Figures 8 and 9 show the discharge coefficients of the experimental and numerical tests of inlet grates 1 and 2 . The experimental discharge coefficient values for grates 1 and 2 were between $0.14(10 \mathrm{l} / \mathrm{s})$ and $0.41(50 \mathrm{l} / \mathrm{s})$ and the discharge coefficient values of the numerical simulation were between $0.15(10 \mathrm{l} / \mathrm{s})$ and $0.40(50 \mathrm{l} / \mathrm{s})$. Figure 10 displays the discharge coefficients for grate 3 through $3 \mathrm{D}$ numerical simulation, where the values of $C_{d}$ are between $0.18(10 \mathrm{l} / \mathrm{s})$ and $0.46(50 \mathrm{l} / \mathrm{s})$. The values of the discharge coefficient obtained for the three different types of grates through experimental and numerical simulation demonstrate that a numerical approach could substitute for experimental tests to achieve accurate discharge coefficient values. Furthermore, it was demonstrated that discharge coefficient values are quite far from the usual value of 0.6 and vary depending on grate type and outflow rate.
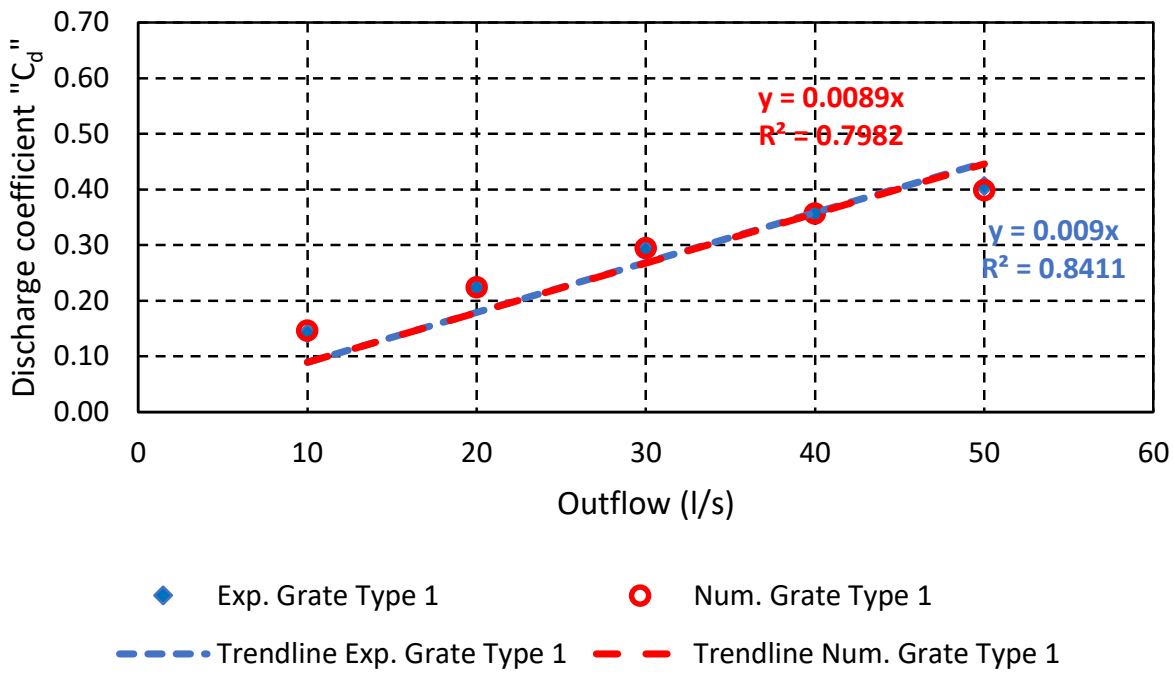

Figure 8. Comparison of discharge coefficients from experimental data vs. numerical simulation for grate 1 .

A summary of the discharge coefficients for each flowrate for both the experimental and numerical tests is shown in the Table 2. The numerical procedure to determine the values of $C_{d}$ presents a good approximation of the experimental values. This creates the opportunity to simulate more inlet grates and outflows using the numerical model, which is significantly less time consuming. 


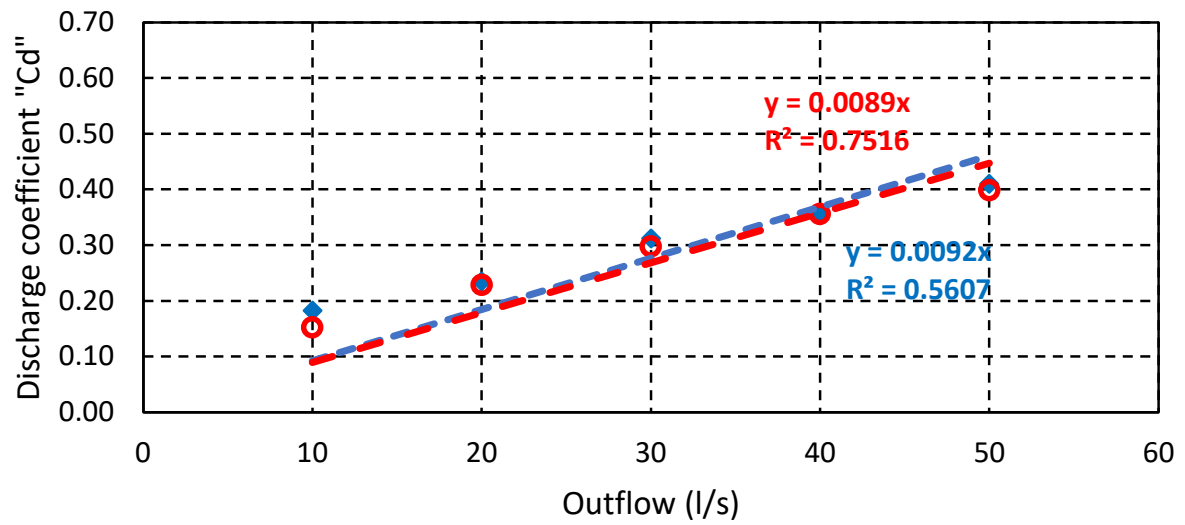

- Exp. Grate Type 2

- Num. Grate Type 2

- - Trendline Exp. Grate Type 2 - Trendline Num. Grate Type 2

Figure 9. Comparison of discharge coefficients from experimental data vs. numerical simulation for grate 2.

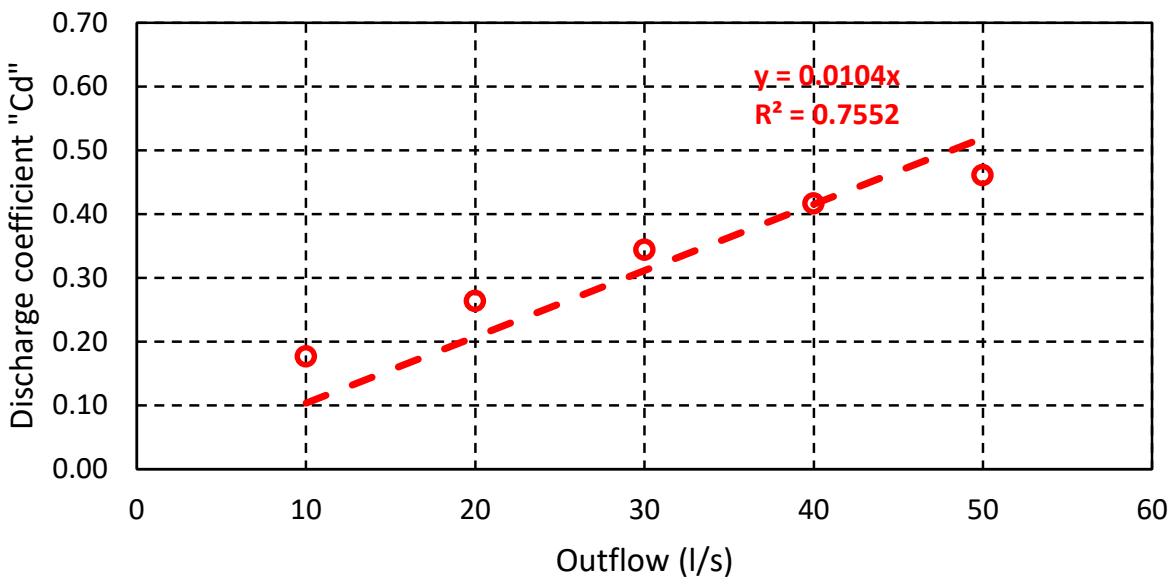

- Num. Grate Type $3 \quad$ - Trendline Num. Grate Type 3

Figure 10. Discharge coefficient results for numerical simulation of grate 3.

Table 2. Discharge coefficient values of grate inlets.

\begin{tabular}{cccccc}
\hline $\begin{array}{c}\text { Flowrate } \\
(\mathbf{1} / \mathbf{s})\end{array}$ & $\begin{array}{c}\text { Grate Type 1 } \\
\text { Exp. } \boldsymbol{C}_{\boldsymbol{d}}\end{array}$ & $\begin{array}{c}\text { Grate Type 1 } \\
\text { Num. } \boldsymbol{C}_{\boldsymbol{d}}\end{array}$ & $\begin{array}{c}\text { Grate Type 2 } \\
\text { Exp. } \boldsymbol{C}_{\boldsymbol{d}}\end{array}$ & $\begin{array}{c}\text { Grate Type 2 } \\
\text { Num. } \boldsymbol{C}_{\boldsymbol{d}}\end{array}$ & $\begin{array}{c}\text { Grate Type 3 } \\
\text { Num. } \boldsymbol{C}_{\boldsymbol{d}}\end{array}$ \\
\hline 10 & 0.14 & 0.15 & 0.18 & 0.15 & 0.18 \\
20 & 0.22 & 0.22 & 0.23 & 0.23 & 0.26 \\
30 & 0.29 & 0.29 & 0.31 & 0.30 & 0.34 \\
40 & 0.36 & 0.36 & 0.36 & 0.36 & 0.42 \\
50 & 0.41 & 0.40 & 0.41 & 0.40 & 0.46 \\
\hline
\end{tabular}

In addition, the energy loss coefficient was also estimated for the three types of grates. The values of energy loss coefficient are more sensitive to inaccuracies in water depth measurements and the effects of turbulence in the flow. The experimental energy loss recorded for grate 1 using flowrates between 20 l/s and 50 l/s was found to be between 3.41 and 0.42 , while the numerical results were between 1.56 and 0.22 (Figure 11). 


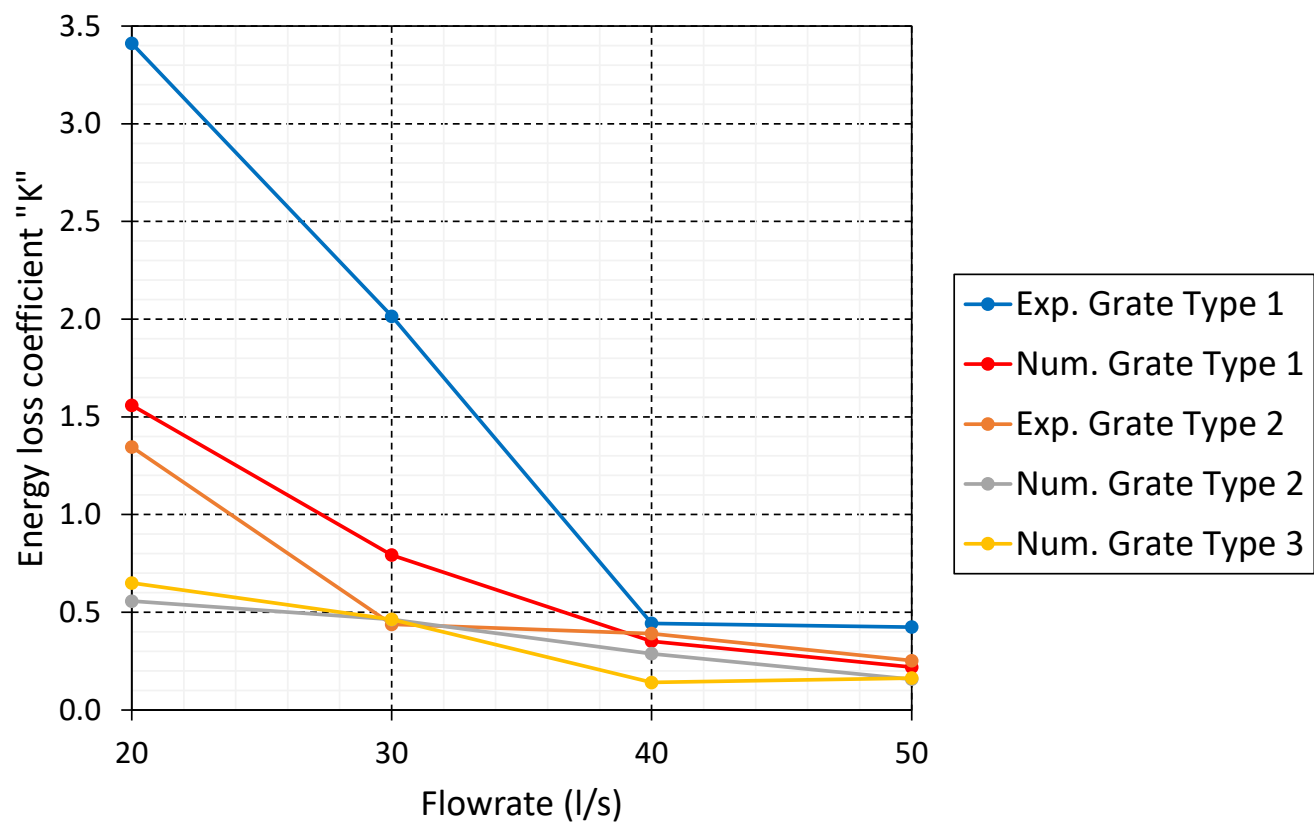

Figure 11. Comparison of energy loss coefficients from experimental data vs. numerical simulation for grates 1, 2 and 3 .

The comparison of energy loss for grate 2 shown in Figure 11 presents a better approximation of the experimental and numerical results of energy loss for the same range of flowrate than that for grate 1 . The experimental energy loss values range between $1.35(20 \mathrm{l} / \mathrm{s})$ and $0.25(50 \mathrm{l} / \mathrm{s})$, and the numerical values range between $0.56(20 \mathrm{l} / \mathrm{s})$ and $0.15(50 \mathrm{l} / \mathrm{s})$. In addition, the energy loss coefficient of grate 3 (Figure 11), as determined by the numerical simulation in Flow 3D, was between $0.65(201 / \mathrm{s})$ and $0.16(50 \mathrm{l} / \mathrm{s})$.

The summary of the values of energy loss coefficients as determined by laboratory tests or numerical simulations in Flow 3D are shown in Table 3.

Table 3. Values of energy loss coefficients of grate inlets.

\begin{tabular}{cccccc}
\hline $\begin{array}{c}\text { Flowrate } \\
(\mathbf{1} / \mathbf{s})\end{array}$ & $\begin{array}{c}\text { Grate Type 1 } \\
\text { Exp. } \boldsymbol{k}\end{array}$ & $\begin{array}{c}\text { Grate Type 1 } \\
\text { Num. } \boldsymbol{k}\end{array}$ & $\begin{array}{c}\text { Grate Type 2 } \\
\text { Exp. } \boldsymbol{k}\end{array}$ & $\begin{array}{c}\text { Grate Type 2 } \\
\text { Num. } \boldsymbol{k}\end{array}$ & $\begin{array}{c}\text { Grate Type 3 } \\
\text { Num. } \boldsymbol{k}\end{array}$ \\
\hline 20 & 3.41 & 1.56 & 1.35 & 0.56 & 0.65 \\
30 & 2.02 & 0.79 & 0.44 & 0.49 & 0.46 \\
40 & 0.44 & 0.35 & 0.39 & 0.29 & 0.14 \\
50 & 0.42 & 0.22 & 0.25 & 0.15 & 0.16 \\
\hline
\end{tabular}

\section{Conclusions}

The flow transfer from the subsurface sewer systems to surface model is a key feature of integrated flood models in urban areas. The accuracy of this transfer is essential to the quality of flood predictions. The discharge coefficients used to characterize the hydraulic performance of the pressurized inlet found in this paper are up to four times smaller than the 0.6 recommended by practitioners. An error of this magnitude is likely to cause notable inaccuracies in large simulations of coupled models. As the coefficients in the orifice equation can be stipulated in most commercial models, grate manufacturers could provide these values under both draining and surcharging conditions.

In the field of pressurized grate inlets, head loss coefficient $k$ and discharge coefficient $C_{d}$ are related to the same physical phenomenon: the energy lost by the flow through the grate. This paper analyzes these two parameters at experimental and numerical levels.

Specifically, using both a full-scale experimental and a numerical model, the discharge coefficient of a surcharging inlet grate was calculated for flowrates between $10 \mathrm{l} / \mathrm{s}$ and $50 \mathrm{l} / \mathrm{s}$. The numerical simulation for grates 1 and 2 replicates the experimental values of 
the discharge coefficient, ranging between 0.14 and 0.41 . Both datasets indicate that the discharge coefficient is larger with a higher surcharging flowrate. It was concluded that the longitudinal gradient of the platform has no effect on the discharge coefficient, and therefore future tests can be conducted on a platform with a $0 \%$ longitudinal gradient. Furthermore, the numerical procedure to determine the values of $C_{d}$ present a good approximation in comparison with the experimental values. This creates the opportunity to simulate more inlet grates and flow rates using the numerical model, which is a faster and less expensive approach.

The comparison of the experimental and numerical simulation results shows a range of values of discharge coefficient between 0.13 and 0.41 for a flow rate surcharge between 10 and 50 l/s; results of 3D numerical simulation shows a range of discharge coefficient between 0.15 and 0.40 .

The energy loss coefficient was investigated for three types of grates. The energy loss recorded for flowrates between $201 / \mathrm{s}$ and $50 \mathrm{l} / \mathrm{s}$ was found to be between 0.15 and 3.41, showing a negative correlation. This parameter presents more variation in the results; it is clear that the effect of the turbulence and measurement of the water level affect the results of $k$.

Author Contributions: Conceptualization, M.G. and B.R.; methodology, J.T.-A.; formal analysis and data curation, J.T.-A. and M.A.-K.; writing—original draft preparation, J.T.-A. and M.A.-K.; writing-review and editing, M.G., M.A.-K., J.T.-A. and B.R. All authors have read and agreed to the published version of the manuscript.

Funding: This research received no external funding.

Institutional Review Board Statement: Not applicable.

Informed Consent Statement: Not applicable.

Data Availability Statement: The data presented in this study are available on request from the corresponding author.

Conflicts of Interest: The authors declare no conflict of interest.

\section{References}

1. Ashley, M.R.; Balmfort, D.J.; Saul, A.J.; Blanksy, D.J. Flooding in the future- predicting climate change, risks and responses in urban areas. Water Sci. Technol. 2005, 52, 265-273.

2. Un.org. World's Population Increasingly Urban with More than Half Living in Urban Areas | UN DESA | United Nations Department of Economic and Social Affairs. 2014. Available online: http://www.un.org/en/development/desa/news/ population/world-urbanization-prospects-2014.html (accessed on 2 January 2019).

3. Ortiz, A.; Velasco, M.J.; Esbri, O.; Medina, V.; Russo, B. The economic impact of climate change on urban drainage master planning in Barcelona. Sustainability 2021, 13, 71. [CrossRef]

4. Russo, B.; Velasco, M.; Locatelli, L.; Sunyer, D.; Yubero, D.; Monjo, R.; Martínez-Gomariz, E.; Forero-Ortiz, E.; Sánchez-Muñoz, D.; Evans, B.; et al. Assessment of urban flood resilience in Barcelona for current and future scenarios. The RESCCUE Project. Sustainability 2020, 12, 5638. [CrossRef]

5. Russo, B.; Velasco, M.; Monjo, R.; Martínez-Gomariz, E.; Domínguez, J.L.; Sánchez, D.; Gabàs, A.; Gonzalez, A. Assessment of the resilience of Barcelona urban services in case of flooding. The RESCCUE project. Ingeniería del Agua 2020, 24, 101-118. [CrossRef]

6. Brown, R.R. Impediments to integrated urban stormwater management: The need for institutional reform. Environ. Manag. 2005, 36, 455-468.

7. Martins, R.; Leandro, J.; Djordjevic, S. Influence of sewer network models on urban flood damage assessment based on coupled 1D/2D models. J. Flood Risk Manag. 2016, 11, S717-S728. [CrossRef]

8. De St Venant, B. Théorie du mouvement non permanent des eaux, avec application aux crues des rivières et a l'introduction de marées dans leurs lits. Comptes Rendus L'académie Sci. 1981, 73, 148-154.

9. Russo, B.; Sunyer, D.; Velasco, M.; Djordjević, S. Analysis of extreme flooding events through a calibrated 1D/2D coupled model: The case of Barcelona (Spain). J. Hydroinform. 2015, 17, 473-491. [CrossRef]

10. Valentin, M.G.; Macchione, F.; Russo, B. Comportamiento hidráulico de las calles durante lluvias extremas en zonas urbanas. Ing. Hidráulica México 2009, 24, 51-62.

11. Martínez-Gomariz, E.; Gómez, M.; Russo, B.; Sánchez, P.; Montes, J.A. Damage assessment methodology for vehicles exposed to flooding in urban areas. Ingeniería del Agua 2017, 21, 247-262. [CrossRef] 
12. Rubinato, M.; Martins, R.; Shucksmith, J.D. Quantification of energy losses at a surcharging manhole. Urban Water J. 2018, 15, 234-241. [CrossRef]

13. Cosco, C.; Gómez, M.; Russo, B.; Tellez-Alvarez, J.; Macchione, F.; Costabile, P.; Costanzo, C. Discharge coefficients for specific grated inlets. Influence of the Froude number. Urban Water J. 2020, 17, 656-668. [CrossRef]

14. Tellez-Alvarez, J.; Gómez, M.; Russo, B. Quantification of energy loss in two grated inlets under pressure. Water 2020, $12,1601$. [CrossRef]

15. Gómez, M.; Russo, B.; Tellez-Alvarez, J. Experimental investigation to estimate the discharge coefficient of a grate inlet under surcharge conditions. Urban Water J. 2019, 16, 85-91. [CrossRef]

16. Gómez, M.; Russo, B. Methodology to estimate hydraulic efficiency of drain inlets. Water Manag. 2011, 164, 81-90. [CrossRef]

17. Saul, A.; Djordjevic, S.; Maksimovic, C.; Blanksby, J. Flood Risk Science and Management; Wiley-Blackwell: Hoboken, NJ, USA, 2011; pp. 258-291.

18. Djordjević, S.; Prodanović, D.; Maksimović, Č.; Ivetić, M.; Savić, D. SIPSON—Simulation of interaction between pipe flow and surface overland flow in networks. Water Sci. Technol. 2005, 52, 275-283. [PubMed]

19. Glenis, V.; McGough, A.S.; Kutija, V.; Kilsby, C.; Woodman, S. Flood modelling for cities using Cloud computing. J. Cloud Comput. Adv. Syst. Appl. 2013, 2, 7. [CrossRef]

20. Bertsch, R.; Glenis, V.; Kilsby, C. Urban flood simulation using synthetic storm drain networks. Water 2017, 9, 925. [CrossRef]

21. Nones, M.; Caviedes-Voullième, D. Computational advances and innovations in flood risk mapping. J. Flood Risk Manag. 2020, 13, e12666. [CrossRef]

22. Sampson, C.C.; Fewtrell, T.J.; Duncan, A.; Shaad, K.; Horritt, M.S.; Bates, P.D. Use of terrestrial laser scanning data to drive decimetric resolution urban inundation models. Adv. Water Resour. 2012, 41, 1-17. [CrossRef]

23. Bach, P.M.; Rauch, W.; Mikkelsen, P.S.; McCarthy, D.; Deletic, A. A critical review of integrated urban water modelling-Urban drainage and beyond. Environ. Model. Softw. 2014, 54, 88-107. [CrossRef]

24. Rubinato, M.; Lee, S.; Martins, R.; Shucksmith, J.D. Surface to sewer flow exchange through circular inlets during urban flood conditions. J. Hydroinform. 2018, 20, 564-576. [CrossRef]

25. Rubinato, M.; Martins, R.; Kesserwani, G.; Leandro, J.; Djordjević, S.; Shucksmith, J. Experimental calibration and validation of sewer/surface flow exchange equations in steady and unsteady flow conditions. J. Hydrol. 2017, 552, 421-432. [CrossRef]

26. Kidd, C.H.R.; Helliwell, P.R. Simulation of the inlet hydrograph for urban catchments. J. Hydrol. 1977, 35, 159-172. [CrossRef]

27. Djordjević, S.; Prodanović, D.; Maksimović, Č. An approach to simulation of dual drainage. Water Sci. Technol. 1999, 39, 95-103. [CrossRef]

28. Obermayer, A.; Guenthert, F.W.; Angermair, G.; Tandler, R.; Braunschmidt, S.; Milojevic, N. Different approaches for modelling of sewer caused urban flooding. Water Sci. Technol. 2010, 62, 2175-2182. [CrossRef] [PubMed]

29. Schmitt, T.G.; Thomas, M.; Ettrich, N. Analysis and modeling of flooding in urban drainage systems. J. Hydrol. 2004, 299 , 300-311. [CrossRef]

30. Dai, S.; Jin, S.; Qian, C.; Yang, N.; Ma, Y.; Liang, C. Interception efficiency of grate inlets for sustainable urban drainage systems design under different road slopes and approaching discharges. Urban Water J. 2021, 18, 650-661. [CrossRef]

31. Ettrich, N.; Steiner, K.; Thomas, M.; Rothe, R. Surface models for coupled modelling of runoff and sewer flow in urban areas. Water Sci. Technol. 2005, 52, 25-33. [CrossRef]

32. Mark, O.; Weesakul, S.; Apirumanekul, C.; Aroonnet, S.B.; Djordjević, S. Potential and limitations of 1D modelling of urban flooding. J. Hydrol. 2004, 299, 284-299. [CrossRef]

33. Nasello, C.; Tucciarelli, T. Dual multilevel urban drainage model. J. Hydraul. Eng. 2005, 131, 748-754. [CrossRef]

34. Hunter, N.M.; Bates, P.D.; Neelz, S.; Pender, G.; Villanueva, I.; Wright, N.G.; Liang, D.; Falconer, R.A.; Lin, B.; Wallwe, S.; et al. Benchmarking 2D hydraulic models for urban flooding. Water Manag. 2008, 161, 13-30.

35. Vojinovic, Z.; Seyoum, S.D.; Mwalwaka, J.M.; Price, R.K. Effects of model schematisation, geometry and parameter values on urban flood modelling. Water Sci. Technol. 2011, 63, 462-467. [CrossRef]

36. Mason, D.C.; Horritt, M.S.; Hunter, N.M.; Bates, P.D. Use of fused airborne scanning laser altimetry and digital map data for urban flood modelling. Hydrol. Process. 2007, 21, 1436-1447. [CrossRef]

37. Gibson, M.J.; Savic, D.A.; Djordjevic, S.; Chen, A.S.; Fraser, S.; Watson, T. Accuracy and computational efficiency of 2D urban surface flood modelling based on cellular automata. Procedia Eng. 2016, 154, 801-810. [CrossRef]

38. Chen, Y.; Han, D. On big data and hydroinformatics. Procedia Eng. 2016, 154, 184-191. [CrossRef]

39. Russo, B.; Gomez, M.; Martinez, P.; Sanchez, H. Methodology to study the surface runoff in urban streets and the design inlets systems. Application in a real case study. In Proceedings of the 10th International Conference on Urban Drainage, Copenhagen, Denmark, 21-26 August 2005.

40. Pandit, S.K.; Oka, Y.; Shigeta, N.; Watanabe, M. Comparative efficiencies study of slot model and mouse model in pressurised pipe flow. J. Urban Environ. Eng. 2014, 8, 83-88. [CrossRef]

41. Preissmann, A. Propagation des intumescences dans les canaux et rivières. In Proceedings of the First Congress of the French Association for Computation, Grenoble, France, September 1961.

42. Djordjević, S.; Saul, A.J.; Tabor, G.; Blanksby, J.; Galambos, I.; Sabtu, N.; Sailor, G. Experimental and numerical investigation of interactions between above and below ground drainage systems. Water Sci. Technol. 2013, 67, 535-542. [CrossRef] 
43. Bazin, P.-H.; Nakagawa, H.; Kawaike, K.; Paquier, A.; Mignot, E. Modeling flow exchanges between a street and an underground drainage pipe during urban floods. J. Hydraul. Eng. 2014, 140, 04014051. [CrossRef]

44. Butler, D.; Davies, J.W. Urban Drainage; Spon Press: London, UK; New York, NY, USA, 2011.

45. Neenah Foundry Company (NFCO). Inlet Spacing Calculators, Website Applications; Neenah Foundry Company (NFCO): Neenah, WI, USA, 2021.

46. Russo, B.; Gómez, M.; Macchione, F. Pedestrian hazard criteria for flooded urban areas. Nat. Hazards 2013, 69, 251-265. [CrossRef]

47. Martínez-Gomariz, E.; Gómez, M.; Russo, B. Experimental study of the stability of pedestrians exposed to urban pluvial flooding. Nat. Hazards 2016, 82, 1259-1278. [CrossRef]

48. Martínez-Gomariz, E.; Gómez, M.; Russo, B.; Djordjević, S. A new experiments-based methodology to define the stability threshold for any vehicle exposed to flooding. Urban Water J. 2017, 14, 930-939. [CrossRef]

49. Martínez-Gomariz, E.; Gómez, M.; Russo, B.; Djordjević, S. Stability criteria for flooded vehicles: A state-of-the-art review. J. Flood Risk Manag. 2016, 11, S817-S826. [CrossRef]

50. Russo, B.; Gómez, M.; Tellez, J.; Tellez-Alvarez, J. Methodology to estimate the hydraulic efficiency of nontested continuous transverse grates. J. Irrig. Drain. Eng. 2013, 139, 864-871. [CrossRef]

51. Tellez-Alvarez, J. Image Processing and Experimental Techniques to Characterize the Hydraulic Performance of Grate Inlet. Ph.D. Thesis, Technical University of Catalonia, Barcelona, Spain, 2019.

52. Gómez, M.; Sánchez, H.; Malgrat, P.; Castillo, F. Inlet spacing considering the risk associated to runoff: Application to streets and critical points of the City of Barcelona. In Proceedings of the 9th International Conference on Urban Drainage, (ICUD), Barcelona, Spain, 8-13 September 2002.

53. Amezaga-Kutija, M. Assessment of the Discharge Coefficient for a Surcharging Inlet: Numerical and Experimental Comparison. Master's Thesis, Civil Engineering Degree, University of Sheffield, Sheffield, UK, 2019.

54. Flow 3D Version 12.0 Users Manual, Flow 3D (Computer Software); Flow Science, Inc.: Santa Fe, NM, USA, 2019.

55. Gómez, M.; Recasens, J.; Russo, B.; Martínez-Gomariz, E. Assessment of inlet efficiency through a 3D simulation: Numerical and experimental comparison. Water Sci. Technol. 2016, 74, 1926-1935. [CrossRef]

56. Russo, B.; Valentín, M.; Tellez-Álvarez, J. The relevance of grated inlets within surface drainage systems in the field of urban flood resilience. A review of several experimental and numerical simulation approaches. Sustainability 2021, 13, 7189. [CrossRef]

57. Tellez-Alvarez, J.D.; Gómez, M.; Russo, B. Modelling of surcharge flow through grated inlet. In Advances in Hydroinformatics; Springer: Berlin/Heidelberg, Germany, 2020; pp. 839-847. [CrossRef]

58. Bayon, A.; Valero, D.; García-Bartual, R.; Vallés-Morán, F.; López-Jiménez, P.A. Performance assessment of OpenFOAM and FLOW-3D in the numerical modeling of a low Reynolds number hydraulic jump. Environ. Model. Softw. 2016, 80, 322-335. [CrossRef]

59. Morovati, K.; Eghbalzadeh, A. Study of inception point, void fraction and pressure over pooled stepped spillways using Flow-3D. Int. J. Numer. Methods Heat Fluid Flow 2018, 28, 982-998. [CrossRef] 